\title{
Forecast of potential rockburst hazard during the reconstruction of the Yugo-Zapadnaya mine at the Darasun deposit
}

\author{
Elena L. Sosnovskaia ${ }^{1 *}$, Arkadii N. Avdeev ${ }^{1}$ \\ 1 Institute of Mining UB RAS, Ekaterinburg, Russia \\ *e-mail: avdeev0706@mail.ru
}

\begin{abstract}
Research aim is to study the geomechanical conditions of the Yugo-Zapadnaya mine at the Darasun gold ore deposit during the reconstruction of mining to forecast the rockburst hazard.

Methodology. Laboratory tests of physical and mechanical properties of rocks were carried out. The initial stress-strain state of the rock mass was assessed by natural measurements and by solving the inverse geomechanical problem. The method of finite element analysis determined the technogenic stresses in the structural elements of the geotecnologies. Engineering calculations of critical depths of rockbursts were performed.

Results and conclusions. By results of researches it is established, that the natural field of in-situ stresses in the deposit array of rocks is distributed discretely: high-stress, medium-stress and off-load zones are distinguished. The rocks have high strength and elastic properties and are prone to brittle fracture. The actual mining has reached critical depth of rockburst. Air headings and ceiling are in the most hazardous state. To increase the safety of mining, a set of measures has been proposed: unloading roof ceiling and corners with slots, giving the roof a hipped shape, replacing the ceiling with a concrete pillar. It is recommended to conduct operational geomechanical monitoring at the mine.
\end{abstract}

Key words: initial and technogenic stress-strain state; gravitational and tectonic stresses; physical and mechanical properties of rocks; mine workings and pillars; geomechanical conditions; forecast of rockburst hazard.

Acknowledgements. The article has been prepared under the government contract no. 075-0058119-00, theme no. 0405-2019-0007. Methodological fundamentals of zoning the territory of the Russian Federation by the risk of man-made natural disasters conditioned by modern geodynamic crustal movements at hazardous and unique facilities of subsoil use.

Introduction. The ore field of the Darasun gold ore deposit is situated within the gold-molybdenum belt of Eastern Transbaikal. The deposit has complex tectonics, 9 joint systems were distinguished, basically running in the latitudinal, north-eastern and north-western orientation. $1 \mathrm{~m}$ thick rake quartz-sulphide lodes are mined bedded in quartz diorites, gabbro-diorites, amphibolites, and granodiorites. Basically, the method with ore shrinkage and ore preparation is used in the mine. Reserves in a layer are mined bottom-upwards; $3 \mathrm{~m}$ high ceiling is formed when cleaning up blocks. There are no intervening pillars. Lodes have significant strike dimensions, so the unsupported spans of goaf reach 200-300 $\mathrm{m}$ and more.

In the late 1970s in the course of actual mining at the Darasun mine, more than 36 instances of hazardous manifestation of rock pressure were registered. In 1979 the deposit was ranged as rockburst hazardous starting from the depth of $330 \mathrm{~m}[1,2]$. 
In 2006 after the fire which resulted in the destruction and further flooding of a significant part of underground mine workings, mining at the Darasun mine was terminated. The mine is currently under reconstruction, and a section of the deposit, the Yugo-Zapadnaya mine, is recommissioned. Lower 607-717 $\mathrm{m}$ horizons were drained. Current depth of mining makes up 500-700 m.

In order to forecast the rockburst hazard of the rock mass, the geomechaniacl conditions at the lower horizons of the shaft under reconstruction were studied in 2019.

Table 1. Main physical and mechanical properties of rock at the Yugo-Zapadnaya mine Таблица 1. Основные физико-механические свойства горных пород шахты «Юго-Западная»

\begin{tabular}{l|c|c|c|c|c|c|c}
\hline \multicolumn{1}{c|}{ Rock } & $\begin{array}{c}\text { Compres- } \\
\text { sive } \\
\text { strength, } \\
\text { Mpa }\end{array}$ & $\begin{array}{c}\text { Tension } \\
\text { strength, } \\
\mathrm{MPa}\end{array}$ & $\begin{array}{c}\text { Angle of } \\
\text { shear } \\
\text { resistance, } \\
\text { degree }\end{array}$ & $\begin{array}{c}\text { Young's } \\
\text { modulus, } \\
\text { GPa }\end{array}$ & $\begin{array}{c}\text { Poisson's } \\
\text { ratio }\end{array}$ & $\begin{array}{c}\text { Modulus of } \\
\text { deformation, } \\
\text { GPa }\end{array}$ & $\begin{array}{c}\text { Deformation } \\
\text { criterion of } \\
\text { Ia. A. Bich, \% }\end{array}$ \\
\hline $\begin{array}{l}\text { Granite } \\
\text { Quartz dio- }\end{array}$ & 80.6 & 11.8 & 33 & 51.3 & 0.14 & 49.9 & 87.0 \\
rite & 89.4 & 20.0 & 25 & 116.1 & 0.31 & 87.2 & 72.0 \\
Peridotite & 68.6 & 14.8 & 26 & 80.8 & 0.22 & 81.0 & 82.1 \\
Beresite & 52.5 & 8.8 & 30 & 67.2 & 0.22 & 62.6 & 87.8
\end{tabular}

Research material and methodology. In the course of research a complex of methods has been used including laboratory testing of physical and mechanical properties of rocks [3]; the estimation of rock mass initial stresses field with the in-situ measurements, slot relief according the methodology of the Institute of Mining UB RAS [4] and analytical estimation based on the inverse problems solution by the recorded manifestations of rock pressure [5]; finite-element modelling of technogenic stresses at the contour of the mine workings and pillars [6-9], engineering analysis of rockburst critical depths in hazardous elements of the underground structures [10-11].

Table 2. The results of measurements of the initial rock mass stresses at the Yugo-Zapadnaya mine

Таблица 2. Результаты измерений первоначальных напряжений массива горных пород на шахте «Юго-Западная»

\begin{tabular}{c|c|c|c}
\hline \multirow{2}{*}{$\begin{array}{c}\text { Observation stations } \\
\text { depth, } \mathrm{m}\end{array}$} & \multicolumn{3}{|c}{ Stresses, MPa } \\
\cline { 2 - 4 } & Vertical & \multicolumn{2}{|c}{ Horizontal } \\
\cline { 2 - 4 } & & longitudinal & transverse \\
\hline 507 & $-15.0 \pm 3.0$ & $-14.8 \pm 4.5$ & $-23.0 \pm 2.6$ \\
617 & $-16.7 \pm 1.4$ & $-10.4 \pm 0.3$ & $-9.3 \pm 1.6$
\end{tabular}

Results. Evaluation of physical and mechanical properties of rocks. According to the results of laboratory testing of samples collected in May 2019 from the cores of the prospect holes and hand specimen, it has been determined that the rock of the lower horizons at the Yugo-Zapadnaya mine possess high elastic and strength properties (table 1). Deformation criterion of Ia. A. Bich is $71.95-90.48 \%$, which is higher than the critical value of $70 \%$. Rock can accumulate energy under pressure, i.e. are prone to brittle fracture in rockburst hazardous forms.

Evaluation of the initial stress field. In 2005-2006 the rockburst forecast and prevention service of OOO Darasunskii rudnik (Darasun mine Ltd) recorded 
13 instances of dynamic manifestations of rock pressure at the horizons of 617,667 , $717 \mathrm{~m}$ of the Yugo-Zapadnaya mine. According to the recorded instances, initial stresses in highly rockburst hazardous section were analysed for the conditions of the YugoZapadnaya mine based on the inverse geomechanical problem solution. The following has been obtained as per calculation. Medium vertical stresses are-19.4 MPa, horizontal stresses along the strike of the ore bodies are $-56.8 \mathrm{MPa}$, and cross-line stresses are -43.6 MPa. Mean coefficient of the horizontal stress (the ratio between the horizontal and vertical stresses) at the sections of rock pressure dynamic manifestation is 2.7 . This ratio is close to the earlier one determined according to the manifestations of rock pressure recorded in 1979-1991 at the Darasun mine, equal to 3.0 [5]. Mean tectonic component is $-39.6 \mathrm{MPa}$ (minus denotes rock contraction), which meets, within the accuracy of measurements, the value of tectonic stresses at rockburst hazardous sections of the Darasun mine [5].

It should be noted that after flooding and further draining of the excavations in 2018-2019 there were no signs of dynamic manifestations of rockburst hazard at the mine.

In June 2019 rock pressure observation stations were placed at the newly operated horizons of $507 \mathrm{~m}$ and $617 \mathrm{~m}$ at the YugoZapadnaya mine, and initial stressed were evaluated by the method of slot relief (table 2) [12]. As a result of measurements it has been stated that at the horizon of $507 \mathrm{~m}$ at the YugoZapadnaya mine which was not flooded, medium gravitational-tectonic stresses act. Minor stresses act vertically and are determined only by the weight of the superincumbent rock; the tectonic component is close to zero. Maximum stresses act across the strike of the ore lode. Horizontal stresses tectonic component makes up -9.6 MPa and

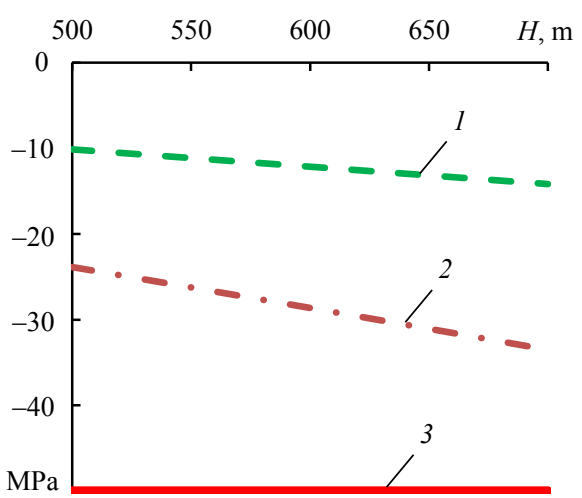

Fig. 1. Technogenic stresses in high-stress surrounding rocks of advanced headings: $H$ - mining depth; $\sigma$-stresses; 1 - the line of stresses in the walls of the roads; 2 - the line of stresses in the roof and roof corners; 3 - the line of permissible stresses

Рис. 1. Техногенные напряжения на контуpe рудных штреков в высоконапряженных участках массива горных пород:

$H$ - глубина горных работ; $\sigma$ - напряжения; 1 - в стенках штреков, 2 - в кровле и углах кровли, 3 - линия допустимых напряжений $-17.8 \mathrm{MPa}$ correspondingly being close to the values of $-12.9 \mathrm{MPa}$ and $-18.0 \mathrm{MPa}$ which are average values with respect to the Darasun deposit [5]. The coefficient of the horizontal stress is 1.0 along the strike of the ore lode and 1.5 across the strike. These values are close to the specified values for the fields of natural stresses of lode gold ore fields of Eastern Siberia, 0.95 and 1.6 [11].

Initial stresses measurement results at the underlying horizon of $617 \mathrm{~m}$ differ significantly from the stresses at the horizon of $507 \mathrm{~m}$. Vertical stresses still depend only on the response of the rock mass weight, their tectonic component is $-0.1 \mathrm{MPa}$. Horizontal stresses are lower than the vertical ones, their tectonic component is $-3.5 \ldots-4.6 \mathrm{MPa}$ under the horizontal stress coefficient of $0.6-0.7$. So, in the marginal mass of the horizon of $617 \mathrm{~m}$, close-to-gravitational stresses act. The authors believe that it is due to the fact that all workings of the horizon of $617 \mathrm{~m}$ and the underlying horizons were flooded up to 2018. The mass apparently unloaded due to crack extension as a result of the multi-year hydraulic head.

Based on the above it can be concluded that at the Yugo-Zapadnaya mine the field of natural stress-strain state is of a discrete nature: both medium-stress zones of the 
mass are distinguished which were not flooded and possess no apparent manifestations of rock pressure (hor. 507 and higher), and off-load zones of the marginal massif at the flooded horizons. High-stress zones are currently not determined at the functioning mining levels; in 2018-2019 hazardous manifestations of rock pressure were not recorded. However, with further development of mining at the shaft they apparently will show.

The analysis of technogenic stresses simulation in the structural elements of the development system makes it possible to note the following.

Table 3. Technogenic stresses in the ceiling pillars

Таблица 3. Техногенные напряжения в потолочине

\begin{tabular}{l|c|c|c|c}
\hline \multirow{2}{*}{ Level of initial stresses } & \multirow{2}{*}{$\begin{array}{c}\text { Mining depth } \\
H, \mathrm{M}\end{array}$} & \multicolumn{3}{|c}{ Technogenic stresses, MPa } \\
\cline { 3 - 5 } & & 50 & 100 & 200 \\
\cline { 3 - 5 } Off-load mass & 500 & -23.3 & -30.1 & -33.6 \\
& 600 & -28.0 & -36.2 & -40.4 \\
& 700 & -31.9 & -41.1 & -45.9 \\
Medium-stress mass & 500 & -73.2 & -95.6 & -107.3 \\
& 600 & -87.9 & -114.7 & -128.7 \\
High-stress mass & 700 & -101.3 & -132.2 & -148.4 \\
& 500 & -137.3 & -179.6 & -201.6 \\
& 600 & -164.7 & -215.5 & -241.9 \\
& 700 & -192.1 & -251.3 & -282.1
\end{tabular}

The most stable elements of permanent mine workings in the studied conditions of the Yugo-Zapadnaya mine are the roof corners and the roof. Nevertheless, the stresses within, both in the medium-stress rock of hor. $507 \mathrm{~m}$ and in the off-load zones of hor. $617-717 \mathrm{~m}$, are minor and do not exceed permissible compressive stresses by the dynamic manifestations of rock pressure ( $70 \%$ from rock compressive strength). It can be concluded that there are basically single drifts to the depths of 500-700 m, except for the local zones with high tectonic stress that will be stable and not rockburst hazardous.

At the air headings abutment the most hazardous are: at the off-load zones - roof corners, at the medium-stress zones - roof corners and walls; at the high-stress zones - roof and walls. The indicated zones will be unstable. The rated critical depth over rockburst here makes up $270 \mathrm{~m}$. At the contour of the advanced headings, stresses do not exceed permissible values even under high tectonic stresses because the developed stope has the effect of relief on the countergangways (fig. 1). Advanced headings are in the stable and not rockburst hazardous state.

At the ceiling (arch pillar) of the stope, stresses exceed permissible values. The bigger the span of the goaf along the strike is, the higher will be the stresses at the arch pillar (ceiling) (table 3). The formed ceiling is the concentrator of increased technogenic stresses. The ceiling is at the unstable and potentially rockburst hazardous state at all depths under investigation.

The walls of the goaf are recorded to have significant tension stresses. So, when panel $50 \mathrm{~m}$ high, tension stresses have been recorded reaching $+121 \ldots+164 \mathrm{MPa}$. Naturally, in real conditions, there will be no such focuses of tension stresses even in high-stress rockburst hazardous zones. Stope walls will destroy with the excavation of the ore body in the forms of intensive fracturing, flaking, detachment, and sometimes fall-off. The thickness of the collapse zone, however, does not depend of the span 
of the goaf. Having reached the value of $h=4.5 \mathrm{~m}$ after the excavation of one panel, subsequently, under the general goaf span increase of $100 \mathrm{~m}$ and more, it will grow up to the values of $L=4.8-5.0 \mathrm{~m}$ (fig. 2). So, the collapse zone in the goaf walls with the working thickness of $1 \mathrm{~m}$ makes up from 3 to $5 \mathrm{~m}$ of lode working thickness. These results are well within the research of the specialists from OJSC Irgiredmed, who established the zone of displacement in the vicinity of the goaf equal to 4.5 thicknesses of the ore body for the conditions of $1 \mathrm{~m}$ thick narrow lodes excavation.

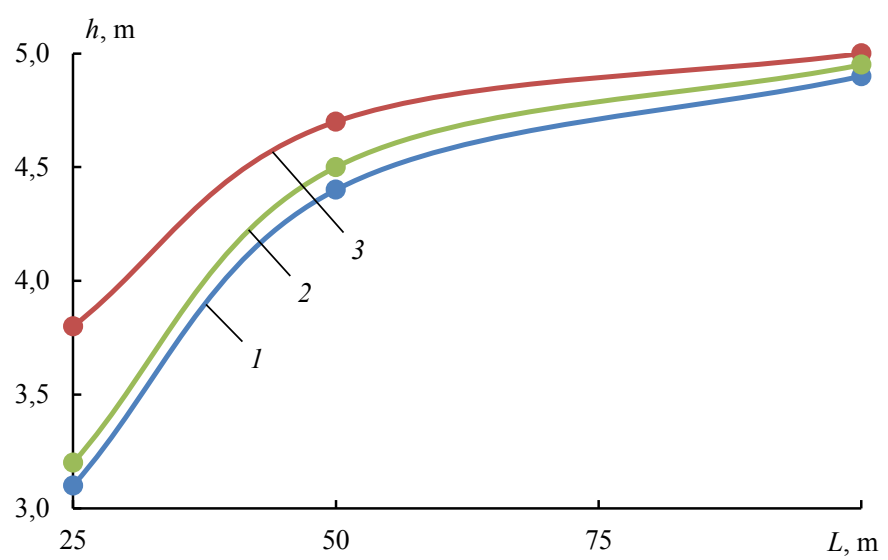

Fig. 2. Thickness of the crumbling layer in the walls of the goaf: $h$ - thickness of the crumbling layer; $L$ - length of the goaf along strike of the lode; $1,2,3$ - respectively off-load, medium and high-stress zones of the rock mass

Рис. 2. Толщина разрушающегося слоя в стенках выработанного пространства:

$h$ - толщина разрушающегося слоя; $L$ - пролет выработанного пространства по простиранию жилы; $1,2,3$ - разгруженные, средненапряженные и высоконапряженные участки массива горных пород

Conclusions. Based on the research on the geomechanical conditions of the YugoZapadnaya mine of the Darasun mine the following conclusions can be made.

It has been determined that the natural field of stresses in the rock mass of the mine is distributed discretely: at hor. $507 \mathrm{~m}$ and higher the field has the gravitational-tectonic character. At hor. $617 \mathrm{~m}$ and lower, off-load zones of gravitational stresses are situated. Rock and ore have high strength and elastic properties and are apt to accumulate energy under pressure being potentially rockburst hazardous.

The actual depth of mining has reached its critical values in rockburst pressure manifestation. Critical depth for the conditions of the Yugo-Zapadnaya mine is 460-600 m: $600 \mathrm{~m}$ at off-load and flooded zones, and $460 \mathrm{~m}$ in naturally dry zones.

Permanent mine workings and air headings are in potentially rockburst hazardous state. At the marginal massif of the hanging and the lower sides of the goaf, the zone of intensive shifts and cavings has been determined equal to 5 working zones of the lode, which makes up $5 \mathrm{~m}$ for the conditions of the narrow lodes at the Darasun deposit. The most hazardous structural element of the geotechnology is the ceiling.

To improve the safety of mining, a complex of measures is proposed: mine workings ceiling and roof corners relief by slots, hipped roof design, and replace the ceiling with an artificial pillar.

Considering the absence of the outer indicators of rockburst hazard after shaft draining in 2018, gravitational natural field of stresses at the lower horizons, the horizons of 507-717 $\mathrm{m}$ at the Yugo-Zapadnaya mine may currently be categorized as 
"non-hazardous". Rock pressure is forecast basically in statistical forms of fracturing, flaking, detachment, and fall-off.

Considering recorded dynamic manifestations of rock pressure at the mine before the accident in 2006, high strength and elastic properties of rock ad ore, gravitational-tectonic character of natural stresses in flooded zones of the massif, high technogenic stresses in stope walls and ceiling together with the fact that the actual depth of mining at the YugoZapadnaya mine has reached its critical values as for the dynamic manifestations of rock pressure, further development of mining may evidently face rock pressure manifestations in dynamic forms. In order to improve the safety of mining it is recommended to fulfill on-line geomechanical monitoring using visual and acoustic methods. At the most hazardous zones, i.e. in the vicinity of the tectonic faults, at the contacts of rock with different strength, superimposed mine workings, and in the zone of extraction influence, it is proposed that rock pressure observation stations should be placed.

\section{REFERENCES}

1. Sosnovskii L. I., Rashkin A. V., Garash Iu. Iu. Manifestations of rock pressure at great depths when carrying out underground works at the Darasun goldfield. In: 50 years anniversary of Transbaikal mines inspection: collected works. St. Petersburg-Chita. p. 139-141. (In Russ.)

2. Neganov V. P. (ed.) Goldfields development technique. Moscow: Nedra Pushing; 1995. (In Russ.)

3. The ISRM suggested methods for rock characterization, testing and monitoring: 2007-2014. Under the editorship of R. Ulusay, Springer International Publishing. Switzerland, Cham, 2015, 293 p.

4. Zubkov A. V. Geomechanics and geotechnology. Ekaterinburg: UB RAS Publishing; 2001. (In Russ.)

5. Sosnovskii L. I. Geoinformational model of the stress condition of Darasun gold ore deposit massive. Marksheideriia i nedropolzovanie = Mine Surveying and Subsurface Use. 2007; 4: 61-64. (In Russ.)

6. Reddy J. N. An introduction to nonlinear finite element analysis. Oxford: Oxford University Press, 2004. $488 \mathrm{p}$.

7. Kattan P. I., Voyiadjis G. Z. Damage mechanics with finite elements: practical application with computer tools. Berlin: Springer, 2002. 113 p.

8. Wilhelm Rust. Non-linear finite element analysis in structural mechanics. Switzerland: Springer International Publishing, 2015. 363 p.

9. Moatamedi M., Hassan A. Khawaja. Finite element analysis. Boca Raton: CRC Press, 2018. 154 p.

10. Sosnovskaia E. L., Avdeev A. N. The forecast of potential rock bump hazard of steeply pitching lode gold ore deposits. Izvestiya vysshikh uchebnykh zavedenii. Gornyi zhurnal = News of the Higher Institutions. Mining Journal. 2016; 2: 74-85. (In Russ.)

11. Sosnovskaia E. L., Avdeev A. N. Control over the geomechanical processes at the goldfields of Eastern Siberia. Izvestiya vysshikh uchebnykh zavedenii. Gornyi zhurnal = News of the Higher Institutions. Mining Journal. 2019; 5: 21-29 (In Eng.). DOI: 10.21440/0536-1028-2019-5-21-29

12. Avdeev A. N., Sosnovskaia E. L., Bolotnev A. Iu. Initial stress-strain state of the Yugo-Zapadnaya mine lower horizons. Nauki o Zemle $i$ nedropolzovanie = Technology and Engineering of Deposit Development. 2019; 42 (3): 325-335. DOI: 10.25635/IM.2019.18.38241 (In Russ.)

Received 10 January 2020

\section{Information about authors:}

Elena L. Sosnovskaia - PhD (Geology and Mineralogy), senior researcher, Laboratory of Geodynamics and Rock Pressure, Institute of Mining UB RAS. E-mail: stress.igd@mail.ru

Arkadii N. Avdeev - PhD (Engineering), senior researcher, Laboratory of Geodynamics and Rock Pressure, Institute of Mining UB RAS. E-mail: avdeev0706@mail.ru

\section{Прогноз потенциальной удароопасности при реконструкции шахты «Юго-Западная» Дарасунского месторождения}

Сосновская Е. Л. ${ }^{1}$, Авдеев А. Н. ${ }^{1}$

${ }^{1}$ Институт горного дела УрО РАН, Екатеринбург, Россия.

\section{Peфераm}

Цель. Исследование геомеханических условий иахты «Юго-Западная» Дарасунского месторождения при восстановлении горных работ с иелью прогноза удароопасности.

Методы. Проведены лабораторные испытания физико-механических свойств горных пород. Натурными измерениями и путем решения обратной геомеханической задачи произведена оценка 
первоначального напряженно-деформированного состояния массива горных пород. Методом конечно-элементного анализа определены техногенные напряжения в конструктивных элементах системы разработки. Проведены инженерные расчеты критических глубин по горным ударам.

Результаты и выводы. По результатам исследований установлено, что естественное поле напряжении в массиве горных пород месторождения распределено дискретно: выделяются локальные участки повышенных тектонических напряжений, средненапряженные участки $u$ разгруженные области приконтурного массива горных пород. Горные породы обладают высокими прочностными и упругими свойствами, склонны к хрупкому разрушению. Фактическая глубина горных работ достигла критических значений по горным ударам. В наиболее удароопасном состоянии находятся вентиляционные итреки $u$ подштрековые целики. Для повышения безопасности горных работ рекомендуется комплекс мероприятий: разгрузка потолочины и углов кровли выработок щелями, придание кровле шатровой формы, замена потолочины искусственным ичеликом. На руднике рекомендуется проводить оперативный геомеханический мониторинг.

Ключевые слова: естественное $и$ техногенное напряженно-деформированное состояние; гравитационные и тектонические напряжения; физико-механические свойства горных пород; горные выработки и иелики; геомеханические условия; прогноз удароопасности.

Статья подготовлена в рамках Госзадания № 075-00581-19-00. Тема № 0405-2019-0007. Методические основы районирования территории Российской Федерации по риску техноприродных катастроф, обусловленных современными геодинамическими движениями земной коры, на опасных и уникальных объектах недропользования.

\section{БИБЛИОГРАФИЧЕСКИЙ СПИСОК}

1. Сосновский Л. И., Рашкин А. В., Гараш Ю. Ю. Проявления горного давления на больших глубинах при ведении подземных горных работ на Дарасунском золоторудном месторождении // 50 лет Горному надзору Забайкалья: сб. статей. СПб-Чита. С. 139-141.

2. Технология разработки золоторудных месторождений / под ред. В. П. Неганова. М: Недра, 1995. $336 \mathrm{c}$.

3. The ISRM suggested methods for rock characterization, testing and monitoring: 2007-2014. Under the editorship of R. Ulusay, Springer International Publishing. Switzerland, Cham, 2015, 293 p.

4. Зубков А. В. Геомеханика и геотехнология. Екатеринбург: УрО РАН, 2001. 335 с.

5. Сосновский Л. И. Геоинформационная модель напряженного состояния горного массива Дарасунского золоторудного месторождения // Маркшейдерия и недропользование. 2007. № 4. С. 61-64.

6. Reddy J. N. An introduction to nonlinear finite element analysis. Oxford: Oxford University Press, 2004. $488 \mathrm{p}$.

7. Kattan P. I., Voyiadjis G. Z. Damage mechanics with finite elements: practical application with computer tools. Berlin: Springer, 2002. 113 p.

8. Wilhelm Rust. Non-linear finite element analysis in structural mechanics. Switzerland: Springer International Publishing, 2015.363 p.

9. Moatamedi M., Hassan A. Khawaja. Finite element analysis. Boca Raton: CRC Press, 2018. 154 p.

10. Сосновская Е. Л., Авдеев А. Н. Прогноз потенциальной удароопасности крутопадающих жильных золоторудных месторождений // Известия вузов. Горный журнал. 2016. № 2. С. 74-85.

11. Сосновская Е. Л., Авдеев А. Н. Управление геомеханическими процессами на золоторудных жильных месторождениях Восточной Сибири // Известия вузов. Горный журнал. 2019. № 5. C. 21-29 (In Eng.). DOI: 10.21440/0536-1028-2019-5-21-29

12. Авдеев А. Н., Сосновская Е. Л., Болотнев А. Ю. Естественное напряженно-деформированное состояние нижних горизонтов шахты «Юго-Западная» Дарасунского рудного поля // Науки о Земле и недропользование. 2019. Т. 43. № 3. С. 325-335. DOI: 10.25635/IM.2019.18.38241

Поступила в редакцию 10 января 2020 года

\section{Сведения об авторах:}

Сосновская Елена Леонидовна - кандидат геолого-минералогических наук, старший научный сотрудник лаборатории геодинамики и горного давления Института горного дела УрО РАН. E-mail: stress.igd@mail.ru

Авдеев Аркадий Николаевич - кандидат технических наук, старший научный сотрудник лаборатории геодинамики и горного давления Института горного дела УрО РАН. E-mail: avdeev0706@mail.ru

Для цитирования: Сосновская Е. Л., Авдеев А. Н. Прогноз потенциальной удароопасности при реконструкции шахты «Юго-Западная» Дарасунского месторождения // Известия вузов. Горный журнал. 2020. № 4. C. 5-11 (In Eng.). DOI: 10.21440/0536-1028-2020-4-5-11

For citation: Sosnovskaia E. L., Avdeev A. N. Forecast of potential rockburst hazard during the reconstruction of the Yugo-Zapadnaya mine at the Darasun deposit. Izvestiya vysshikh uchebnykh zavedenii. Gornyi zhurnal $=$ News of the Higher Institutions. Mining Journal. 2020; 4: 5-11. DOI: 10.21440/05361028-2020-4-5-11 